\title{
Comparison of Different Ultrasonic Vibration Modes for Post Removal
}

\author{
Neilor Mateus Antunes BRAGA ${ }^{1}$ \\ Juliana Monteiro da SILVA2 \\ Jacy Ribeiro de CARVALHO-JÚNIOR ${ }^{3}$ \\ Raquel Conceição FERREIRA ${ }^{1}$ \\ Paulo César SAQUY ${ }^{4}$ \\ Manoel BRITO-JÚNIOR ${ }^{1}$
}

\author{
'Department of Dentistry, UNIMONTES - State University of Montes Claros and Dental School, \\ FUNORTE - United Universities of the North of Minas, Montes Claros, MG, Brazil \\ ${ }^{2}$ Dental School, FUNORTE - United Universities of the North of Minas, Montes Claros, MG, Brazil \\ ${ }^{3}$ Department of Dentistry, School of Health Sciences, UnB - University of Brasilia, Brasilia, DF, Brazil \\ ${ }^{4}$ Department of Restorative Dentistry, Ribeirão Preto Dental School, \\ USP - University of São Paulo, Ribeirão Preto, SP, Brazil
}

\begin{abstract}
This in vitro study compared different ultrasonic vibration modes for intraradicular cast post removal. The crowns of 24 maxillary canines were removed, the roots were embedded in acrylic resin blocks, and the canals were treated endodontically. The post holes were prepared and root canal impressions were taken with self-cured resin acrylic. After casting, the posts were cemented with zinc phosphate cement. The samples were randomly distributed into 3 groups (n=8): G1: no ultrasonic vibration (control); G2: tip of the ultrasonic device positioned perpendicularly to core surface and close to the incisal edge; and G3: tip of the ultrasonic device positioned perpendicularly to core surface at cervical region, close to the line of cementation. An Enac OE-5 ultrasound unit with an ST-09 tip was used. All samples were submitted to the tensile test using an universal testing machine at a crosshead speed of $1 \mathrm{~mm} / \mathrm{min}$. Data were subjected to one-way ANOVA and Tukey's post-hoc tests $(\alpha=0.05)$. Mean values of the load to dislodge the posts (MPa) were: $\mathrm{G} 1=4.6( \pm 1.4) \mathrm{A} ; \mathrm{G} 2=2.8( \pm 0.9) \mathrm{B}$, and G3=0.9 $( \pm 0.3) \mathrm{C}$. Therefore, the ultrasonic vibration applied with the tip of device close to the core's cervical area showed higher ability to reduce the retention of cast post to root canal.
\end{abstract}

Key Words: cast post, post removal, ultrasound.

\section{INTRODUCTION}

Endodontically treated teeth with extensive coronal destruction often require the use of intraradicular posts to retain the crown restoration. Currently, prefabricated fiber posts have increased popularity for this purpose. This post type presents favorable biomechanical behavior and elasticity modulus closer to dentine (1-3). However, cast post and cores have been used with high rate of success for several years, mainly when the restored teeth are pillar of partially fixed or removable dentures (4-6).

A correct diagnosis, observing the remaining dental structure, the radicular anatomy and the quality of root canal filling, is essential to success of restoration retained with intraradicular posts $(2,3,6)$. Negligence of these factors can increase the chance of failure. Thus, post removal can be necessary when the length and/or the diameter of the posts are unsatisfactory, or when the apical seal of the root filling is inadequate, requiring a non-surgical endodontic re-intervention $(7,8)$.

A variety of techniques and instruments for intraradicular post removal has been suggested, such as the use of burs or trephines, devices that grasp the posts so that they can be pulled-out of the root, and the use of ultrasound devices $(8,9)$. The ultrasonic vibration can break the cement and facilitate post removal from the root canal. This technique presents suitable efficiency,

Correspondence: Prof. Dr. Manoel Brito Júnior, Departamento de Odontologia, Universidade Estadual de Montes Claros (UNIMONTES), Avenida Rui Braga, s/n, Vila Mauricéia, 39401-089 Montes Claros, MG, Brasil. Tel: +55-38-3229-8284. e-mail: manoelbritojr@gmail.com 
speed, and safety, while preserving the root integrity (9).

However, several factors may affect the efficiency of ultrasonic vibration during post removal, including the length, form, diameter and type of post, cement type used and post adaptation to the root canal walls (10-14). Furthermore, the efficacy of ultrasound is related to the intensity and movement of the vibration, the type of tip used, and the manner in which the tip is applied on the core $(14,15)$. Regarding the last condition, scientific evidence is still scarce. Thus, the aim of this in vitro study was to compare different ultrasonic vibration modes for intraradicular cast post removal, varying the positioning of the ultrasonic tip on the core. The tested null hypothesis was that the different ultrasonic vibration methods does not influence the load required to remove the cast post from the root canal.

\section{MATERIAL AND METHODS}

A sample of 24 extracted human maxillary canines was selected. The selection criteria were: single-rooted teeth without accentuated flattening, with a single root canal and straight roots measuring approximately 15 $\mathrm{mm}$ in length.

The teeth were sectioned horizontally using a carburundum disc (Dentorium, New York, NY, USA) under air-water cooling to reach a root length of $13 \mathrm{~mm}$. The crowns were discarded. The roots were embedded into self-curing resin acrylic (Orto Class; Clássico, São Paulo, SP, Brazil) cylinders, leaving about $1 \mathrm{~mm}$ of cervical portion exposed.

The roots were treated endodontically, standardizing the working length at $12 \mathrm{~mm}$. The root canals were prepared according to a crown-down technique with a \#50 K-file (Dentsply/Maillefer, Ballaigues, Switzerland) as the master apical file. Canals were irrigated with a $1 \%$ sodium hypochlorite solution (Biodinâmica Produtos Químicos Ltda, São Paulo, SP, Brazil) at each change of file. Smear layer was removed using a 14.3\% EDTA solution (pH 7.4; Odahcam-Herpo Produtos Dentários, Petrópolis, RJ, Brazil) for $3 \mathrm{~min}$ followed by $10 \mathrm{~mL}$ of distilled water. Liquid content was aspired using metal suction tips and the root canals were dried with paper points. Sequentially, the canals were filled by lateral condensation of gutta-percha cones (Dentsply/Maillefer) and an epoxy-resin based sealer (Sealer 26; Dentsply Ind. e Com. Ltda., Petrópolis, RJ, Brazil). The root canal opening was sealed with temporary cement (Coltosol; Vigodent, Rio de Janeiro,
$\mathrm{RJ}$, Brazil) and the specimens were stored at $37^{\circ} \mathrm{C}$ and $100 \%$ humidity for 1 week. After this period, the temporary cement was removed and heated condensers were used to remove up to $5 \mathrm{~mm}$ of the obturation.

Post holes ( $8 \mathrm{~mm}$ depth and $1.7 \mathrm{~mm}$ diameter) were prepared using a \#6 Largo bur (Dentsply/Maillefer) in a low-speed handpiece attached to a parallelometer to ensure that preparations were parallel to the long axis of the roots and to maintain a standardized diameter. Impression of the post holes was taken with chemically activated acrylic resin (Duralay; Reliance Dental, Worth, IL, USA) and prefabricated polycarbonate posts (Pinjet; Angelus, Londrina, PR, Brazil). A ring was attached to the core to facilitate the load application in a universal testing machine (Instron 4444; Instron Corporation, Canton, MA, USA).

Posts and cores were cast with a copper-aluminum alloy (Goldent L.A.; AJE, São Paulo, SP, Brazil). After adjustment of post to root canal, its surface was sandblasted with aluminum oxide particles. The post was $8 \mathrm{~mm}$ long, the core was $5 \mathrm{~mm}$ high, and the ring to be attached to the Instron machine for tensile test had a diameter of approximately $8 \mathrm{~mm}$.

All posts were cemented to root canal using a phosphate zinc cement (S.S.White Dental Products, Rio de Janeiro, RJ, Brazil), mixed following the manufacturer's instructions. The cement was placed on the post surface and into the post-hole using a lentulo spiral, followed by insertion of the post.

The specimens were stored in distilled water at $37^{\circ} \mathrm{C}$ for 1 week and were then randomly divided into 3 groups ( $n=8)$, according to technique of ultrasound application. G1: no ultrasonic vibration application (control group); G2: tip of the ultrasonic device was positioned perpendicularly to core surface and close to the incisal edge (Fig. 1A); G3: tip of the ultrasonic device positioned perpendicularly to core surface at cervical region, close to the line of cementation (Fig. 1B).

In $\mathrm{G} 2$ and $\mathrm{G} 3$, the specimens were fixed to a vise and an ST 09 tip of the ultrasound Enac (Osada Electric Co Ltd., Tokyo, Japan) was employed using maximum power under water cooling by the same calibrated operator. The vibration was applied successively to the buccal, mesial, lingual, and distal surfaces of the core for $15 \mathrm{~s}$ per surface, totalizing $1 \mathrm{~min}$. The vibration application time was recorded using a digital progressive chronometer (Tecnbrás Indústria e Comércio de Equipamentos Eletrônicos Ltda., São Paulo, SP, Brazil). All specimens were positioned to the base of the 
Instron machine and the ring was attached to the load cell. An increasing tensile load was applied at a crosshead speed of $1 \mathrm{~mm} / \mathrm{min}$ until the post was dislodged from the root canal. The results of the tensile test were recorded in MPa and analyzed statistically by one-way ANOVA and Tukey's post-hoc tests $(\alpha=0.05)$.

In this study, the tensile load (F) was related to the post cementation area (A) in order to obtain the tensile bond strength values $(\sigma)$, by means of the equation : $\sigma=$ F/A, where: $\sigma=$ tensile strength, in Pa (Pascal); F $=$ tensile force, in $\mathrm{N} ; \mathrm{A}=$ cementation surface area, in $\mathrm{m}^{2}$ (square meters).

The cementation area is equal to the lateral area (LA) added to the base area (BA), since the upper area of the post was not cemented. Since the post diameter was $1.7 \mathrm{~mm}$, the height was $8 \mathrm{~mm}$ and the post was cone shaped, the final equation was: $\sigma=F / 45$ in $\mathrm{MPa}(10)$.

\section{RESULTS}

The mean tensile load values (MPa) and standard deviations necessary to dislodge the posts after the specific treatment in each group were as follows: G1 $=4.622 \pm 1.366, \mathrm{G} 2=2.753 \pm 0.937$ and G3 $=0.942 \pm$ 0.346 . Statistically significant differences were observed among the three groups $(p<0.01)$. Data were subjected to Bartlett's test in order to verify the variances of the samples. The results showed no differences between variances, which allowed use of the one-way ANOVA test. Thus, specimens submitted to ultrasonic vibration required lowest load to be dislodged from the root canal when compared to samples where the ultrasound was not applied. G3 presented the lowest tensile load values (Tukey's test, $\mathrm{p}<0.01$ ) among all experimental groups.
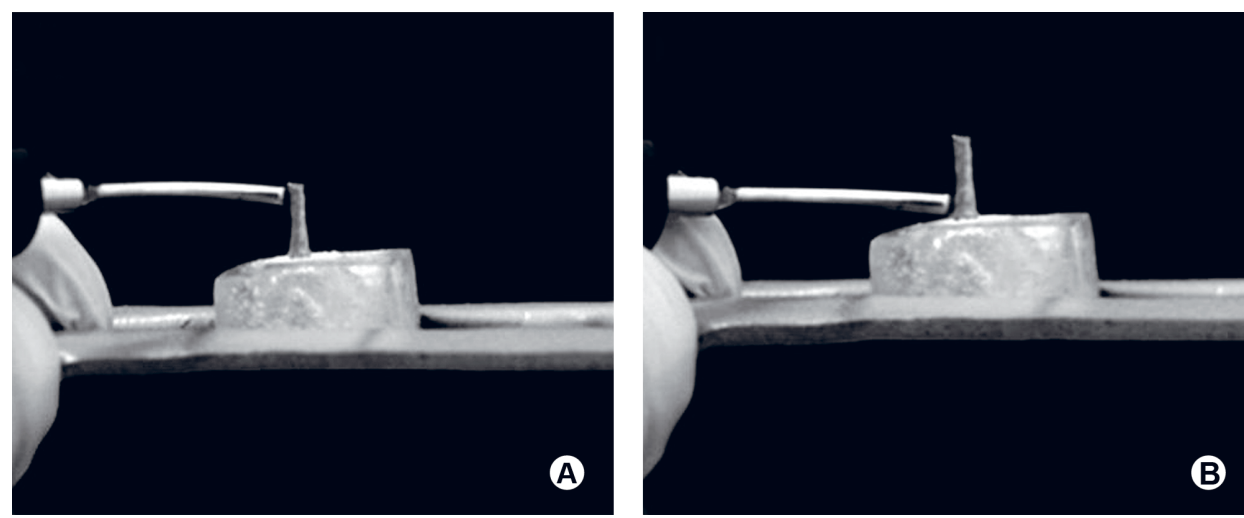

Figure 1. Ultrasonic vibration performed perpendicularly through the core. ST-09 tip applied close to incisal face (A) and close to the core's cervical area (B).

\section{DISCUSSION}

Despite the large number of laboratory protocols described in the literature (10-15), the most suitable condition for running the ultrasonic vibration for predicable intraradicular post removal has not been determined. The present study compared the effect of variations in the application of ultrasonic vibration on retention of cast posts to the root canal. In the present study, an improved performance of the ultrasound was observed when the tip was positioned in the cervical extremity of the core, near the line of cementation. Thus, the null hypothesis was rejected.

During specimen selection for this study, it was observed that a large number of maxillary canines had similar canal morphology, which reduce the anatomical variability. These teeth are generally available and allow deep cementation of posts, facilitating the experimental procedures (15). Usually, the roots of extracted teeth are embedded in resin cylinders in order to facilitate handling and test application. In this step, the simulation of periodontal ligament (PDL) is more consistent with the clinical reality $(15,16)$. In the present study, this procedure was not performed, which could represent a methodological limitation. However, embedding of specimens without simulated PDL is in agreement with the methodology of several studies (10-14) that investigated the performance of the ultrasonic devices for post removal.

The power and the frequency of the ultrasonic waves generated by the device determine the physical characteristics of the vibrations. Piezoelectric devices generate mechanical waves with high-frequency stability transmitting a minimal residual heat to dental structures under water cooling $(17,18)$. For a long time, Enac-Osada, the Japanese-manufactured piezoelectric ultrasound, has been the most widely used apparatus for post removal. Previous experiments evaluating the post removal with an Enac unit used one of the following methodologies: time recording during removal procedures 
and tensile test after ultrasonic vibration (10-16). Comparison of the results of the ultrasound groups and the control group (without ultrasonic vibration) in the present study confirmed the effectiveness of the Enac in reducing the load necessary to remove intraradicular cast posts, as reported elsewhere $(10,14,16)$.

Several studies have reported that the type of luting agent can have an influence on the ultrasonic efficiency for post removal $(12,13)$. Zinc phosphate cement was used in this study because it is the main material used to lute cast posts and cores with a satisfactory performance (19). When an ultrasonic unit is used for post removal, the vibration is transferred to the cement line by the post. Thus, the vibration is expected to cause the cement to fracture and facilitate the post removal procedure. In the present study, the ultrasonic tip of device was successively applied for $15 \mathrm{~s}$ over the buccal, mesial, lingual and distal surfaces of cores (10). This alternate vibration increases the fragmentation of the zinc phosphate cement, thus favoring the detachment of the intraradicular posts $(11,14)$.

It has been postulated that the application of ultrasound tip at the incisal surface maximizes the energy transferred to the post $(11,13,15)$. However, the cervical portion of the core was the most effective site for the application of ultrasonic vibration in the present study. Areasonable explanation for this outcome is that the propagation of ultrasonic energy into an attenuating material decreases with distance. This is due to the conversion of ultrasonic wave into heat or by changing its direction, characterizing absorption and scattering mechanisms, respectively (20). Thus, most part of the ultrasonic vibration applied to the cervical extremity of the core was possibly transferred to the post, thus affecting the integrity of the cementing agent and the cohesive/adhesive micromechanical imbrications among post/cement/root canal walls. When the ultrasound was applied to the proximities of the incisal area of the core, a greater loss of transference of ultrasonic energy possibly occurred. Hence, the rupture of the cement was reduced, demanding higher load to remove the intraradicular posts. Further investigations aimed at evaluating other post systems, post depths and types of cements are necessary to confirm the findings of the present study.

In conclusion, this in vitro study demonstrated that the application of ultrasonic vibration on the cervical area of the core was the most effective procedure for cast post removal.

\section{RESUMO}

Este estudo in vitro comparou diferentes modos de vibração ultra-sônica na remoção de pinos intra-radiculares fundidos. As coroas de 24 caninos superiores foram removidas, as raízes foram incluídas em blocos de resina acrílica e tratadas endodonticamente. Os espaços para os pinos intra-radiculares foram preparados e depois moldados com resina acrílica autopolimerizável. Após a fundição, os pinos intra-radiculares foram cimentados com cimento de fosfato de zinco. As amostras foram distribuídas aleatoriamente em três grupos $(n=8)$ : $G 1$ : sem vibração ultrasônica (controle), G2: ponta do aparelho ultra-sônico posicionada perpendicularmente à superfície do núcleo e perto da borda incisal e G3: ponta do aparelho ultra-sônico posicionada perpendicularmente à superfície do núcleo na região cervical, perto da linha de cimentação. Uma unidade de ultra-som Enac OE-5 com uma ponta ST-09 foi usada. Todas as amostras foram submetidas ao teste de tração utilizando máquina universal de ensaios a uma velocidade de $1 \mathrm{~mm} / \mathrm{min}$. Os dados foram submetidos aos testes ANOVA e Tukey post-hoc $(\alpha=0,05)$. Os valores médios de carga para deslocar os pinos $(\mathrm{MPa})$ foram: $\mathrm{G} 1=4,6( \pm 1,4) \mathrm{A} ; \mathrm{G} 2=2,8$ $( \pm 0,9), \mathrm{B}$ e G3 = 0,9 $( \pm 0,3)$ C. Portanto, a vibração ultra-sônica aplicada com a ponta do dispositivo perto da zona cervical do núcleo apresentou maior capacidade de reduzir a retenção de pinos metálicos fundidos no canal radicular.

\section{REFERENCES}

1. Ferrari M, Cagidiaco MC, Goracci C, Vichi A, Mason PN, Radovic I, et al.. Long-term retrospective study of the clinical performance of fiber posts. Am J Dent 2007;20:287-291.

2. Santos-Filho PC, Castro CG, Silva GR, Campos RE, Soares CJ. Effects of post system and length on the strain and fracture resistance of root filled bovine teeth. Int Endod J 2008;41:493-501.

3. Signore A, Kaitsas V, Ravera G, Angiero F, Benedicenti S. Clinical evaluation of an oval-shaped prefabricated glass fiber post in endodontically treated premolars presenting an oval root canal cross-section: a retrospective cohort study. Int J Prosthodont 2011;24:255-263.

4. Salvi GE, Siegrist Guldener BE, Amstad T, Joss A, Lang NP. Clinical evaluation of root filled teeth restored with or without post-and-core systems in a specialist practice setting. Int Endod J 2007;40:209-215.

5. Fokkinga WA, Kreulen CM, Bronkhorst EM, Creugers NH. Up to 17 -year controlled clinical study on post-and-cores and covering crowns. J Dent 2007;35:778-786.

6. Dietschi D, Duc O, Krejci I, Sadan A. Biomechanical considerations for the restoration of endodontically treated teeth: a systematic review of the literature, Part II (Evaluation of fatigue behavior, interfaces, and in vivo studies). Quintessence Int 2008;39:117-129.

7. Imura N, Pinheiro ET, Gomes BP, Zaia AA, Ferraz CC, SouzaFilho FJ. The outcome of endodontic treatment: a retrospective study of 2000 cases performed by a specialist. J Endod 2007;33:1278-1282.

8. Ruddle CJ. Nonsurgical retreatment. J Endod 2004;30: 827-845.

9. Castrisos T, Abbott PV. A survey of methods used for postremoval in specialist endodontic practice. Int Endod J 2002;35:172-180.

10. Braga NMA, Alfredo E, Vansan IP, Fonseca TS, Ferraz JAB, SousaNeto MD. Efficacy of ultrasound in removal of intraradicular posts using different techniques. J Oral Sci 2005;47:117-121. 
11. Silva MR, Biffi JC, Mota AS, Fernandes Neto AJ, Neves FD Evaluation of intracanal post removal using ultrasound. Braz Dent J 2004;15:119-126.

12. Soares JA, Brito-Júnior M, Fonseca DR, Melo AF, Santos SMC, Sotomayor NCS, et al.. Influence of luting agents on time required for cast post removal by ultrasound: an in vitro study. J Appl Oral Sci 2009;17:145-149.

13. Brito-Junior M, Soares JA, Santos SMC, Camilo CC, Junior GM. Comparison of the time required for removal of intraradicular cast posts using two Brazilian ultrasound devices. Braz Oral Res 2009;23:17-22

14. Garrido ADB, Osorio JED, Silva-Sousa YTC, Sousa-Neto MD Evaluation of several protocols for the application of ultrasound during the removal of cast intraradicular posts cemented with zinc phosphate cement. Int Endod J 2009;42:609-613.

15. Dixon EB, Kaczkowski PJ, Nicholls JI, Harrington GW. Comparison of two ultrasonic instruments for post removal. J Endod 2002;28:111-115.

16. Brito-Junior M, Braga NM, Rodrigues DC, Camilo CC, Fariae-Silva AL. Effect of the simulated periodontal ligament on cast post-and-core removal using an ultrasonic device. J Appl Oral Sci 2010;18:528-532.

17. Lipski M, Debicki M, Droździk A. Effect of different water flows on root surface temperature during ultrasonic removal of posts Oral Surg Oral Med Oral Pathol Oral Radiol Endod 2010;110:395400.

18. Tsurumaki Jdo N, Souto BH, Oliveira GJ, Sampaio JE, Marcantonio Júnior E, Marcantonio RA. Effect of instrumentation using curettes, piezoelectric ultrasonic scaler and Er,Cr:YSGG laser on the morphology and adhesion of blood components on root surfaces: a SEM study. Braz Dent J 2011;22:185-192.

19. Habib B, von Fraunhofer JA, Driscoll CF. Comparison of two luting agents used for the retention of cast dowel and cores. J Prosthodont 2005; 14:164-169.

20. O'Brien Jr WD. Ultrasound-biophysics mechanisms. Prog Biophys Mol Biol 2007;93:212-255

Received August 2, 2011 Accepted December 13, 2011 